\title{
Comparing the Self-Efficacy of Florida School-Based Agricultural Education Teachers Delivering Online and In- Person Instruction
}

\author{
D. M. Barry¹, R. G. Easterly²
}

\begin{abstract}
The purpose of this study was to examine the self-efficacy of Florida SBAE teachers for in-person and online instruction. The methodology included a descriptive survey approach to determine the selfefficacy of Florida SBAE teachers. A census of SBAE teachers was conducted in the Fall of 2020 and Spring of 2021. The population included a total of 500 SBAE teachers in the Florida. Major findings included a significantly different self-efficacy score for in-person instructors $(M=4.22, S D=0.48)$ when compared to instructors who taught online $(M=2.98, S D=0.67)$. Navigating online platforms for teaching, coupled with the conditions in which teachers had to move to online instruction during COVID-19 could have reduced the self-efficacy of teachers. Recommendations include training for teachers on how to navigate online platforms, as well as professional development to enhance skillsets of teachers in pedagogical practices for engaging online learners. Teachers should look for support from their peers who are proficient in online teaching. Preservice teacher education programs should consider integrating online delivery instructional practices into existing coursework and moving back to in-person instruction when it is safe to do so.
\end{abstract}

\section{Keywords}

Agriculture teachers, online teaching, COVID-19, United States

1. Debra M. Barry, Assistant Professor, University of Florida, 1200 N Park Rd, Plant City, FL, 33563, dmbarry@ufl.edu, https://orcid.org/0000-0001-9579-3872

2. R. G. (Tre) Easterly III, Assistant Professor, University of Florida, 305 Rolfs Hall PO Box 110540, Gainesville FL 32611, tre.easterly@ufl.edu, ID https://orcid.org/0000-0003-2807-512X 


\section{Introduction and Problem Statement}

In early 2020, the coronavirus began to make impacts in the United States, with the World Health Organization (WHO) declaring COVID-19 a pandemic by March 2020 (World Health Organization, 2021). The pandemic caused a major shift in the modality of teaching in a matter of days (Cardullo et al., 2021). Teachers were faced with the challenge of moving their instruction from in-person to teaching in an online setting almost overnight (Easterly et al., 2020). Despite the motivation or familiarity with remote instruction, teachers were required to deliver their instruction in a remote setting (Lindner et al., 2020). The impacts of COVID-19 continued to affect education through 2020 and into 2021, leaving many educators with the challenge of teaching a mix of in-person and online in the 2020-2021 school year.

The diversity of subject matter in school-based agricultural education (SBAE) and the responsibilities of managing the FFA organization and supervised agricultural experiences (SAE) add additional complexities to the role of teaching agriculture (Talbert et al., 2014), while recent shifts in teaching modalities in education likely compounded this challenge. While teachers had to make swift changes in their content delivery, they also had to adapt their pedagogical approaches to help support the ability to teach online (Cardullo et al., 2021). According to Cardullo et al. (2021), many teachers were trying to learn how to navigate online platforms while also adapting to the pedagogical shift in online instruction. This study sought to determine the self-efficacy of Florida SBAE teachers for in-person and online instruction, as well as compare the self-efficacy of those teaching each modality.

\section{Theoretical and Conceptual Framework}

Self-efficacy was the theoretical framework for this study (Bandura, 1977a). Self-efficacy determines whether coping behaviors will be initiated, as well as the effort put forth when facing challenging experiences (Bandura, 1977a). Self-efficacy has developed as an important predictor of success for a wide range of tasks, including those of teachers (Bandura, 1995). Teachers reporting higher self-efficacy were found to be more likely to stay committed to teaching as a profession, with lower burnout rates and exhaustion (Klassen \& Chiu, 2011; Zee \& Koomen, 2016). Further research grew from the work of Bandura (1977a); thus, teacher efficacy was acknowledged as a type of self-efficacy (Tschannen-Moran et al., 1998).

Self-efficacy and teacher self-efficacy are developed through mastery experiences, vicarious experiences, social persuasion, and physiological and emotional states (Bandura 1977a, 1986). A teacher with low self-efficacy has a belief that there is modest influence on the motivation of students, with the teacher's influence being limited by their environment. Teachers with higher self-efficacy would be more likely to create learning experiences that engage students, with the belief that their extra efforts will successfully influence the learning environment and their students (Bandura, 1997). It is more likely that a teacher with high self-efficacy would implement a new strategy or approach to teaching (Guskey, 1998). 
Within the framework of K-12 education, teaching self-efficacy has been studied, with the common theme that teachers with high self-efficacy showed positive correlations with the desired outcomes that benefit student learning (Bandura et al., 1996; Goddard et al., 2000; Humphries et al., 2012; Swan et al., 2011; Wolf, 2011). Recent changes in technology illuminate opportunities that seek to understand teacher self-efficacy through the lens of in-person and online instruction, as well as how these modalities affect teacher self-efficacy. Although previous research has explored self-efficacy in school-based agricultural education (McKim \& Velez, 2016), little is known about agriculture teacher self-efficacy in a COVID-19 influenced teaching environment.

The computer and online self-efficacy of learners was explored by Wei and Chou (2020), finding that the perceptions of self-efficacy affected learning readiness. While research has explored the self-efficacy of teachers (Easterly \& Simpson, 2020; McKim \& Velez, 2016; Thornton et al., 2020;), as well as teachers' remote teaching self-efficacy (e.g., Easterly et al., 2020), at the time of this study there had not yet been a study that compared teacher self-efficacy of in-person and online instruction.

\section{Purpose}

The purpose of this study was to examine the self-efficacy of Florida SBAE teachers for inperson and online instruction. The research was guided by the following objectives:

1. Determine the self-efficacy of Florida SBAE teachers for in-person instruction

2. Determine the self-efficacy of Florida SBAE teachers for online instruction

3. Compare the self-efficacy of Florida SBAE teachers for delivering instruction online and inperson.

\section{Methods}

This study used a descriptive survey approach to determine the self-efficacy of Florida SBAE teachers. A census of SBAE teachers in the state of Florida was conducted in the Fall of 2020 with final data collection in the spring of 2021. These data were collected as part of a larger study. The population frame was developed by agricultural education faculty in the Department of Agricultural Education and Communication at the University of Florida in collaboration with the state agricultural education supervisor and the Florida FFA Association office. A total of 515 teachers were contacted. Fifteen teachers were removed from the population because they no longer taught at that school yielding a corrected population frame of $N=500$. The tailored design method described by Dillman et al. (2014) was used. A pre-notice letter with a \$1 cash incentive was mailed to the participants. The initial contact email with the links to a Qualtrics instrument was sent out when the pre-notice letter was expected to arrive. Additional reminder emails were used to encourage responses. Four teachers opted out of the study. Usable data was provided from 248 respondents yielding a response rate of $49.6 \%$. An archival analysis technique was used to test for non-response bias (Johnson \& Shoulders, 2019; Rogelberg \& Stanton, 2007). Chi-square tests were conducted with known variables of the non-respondents. 
No significant difference was found for gender $\left(X^{2}(1, N=500)=1.18, p<.05\right)$ and FFA district $\left(X^{2}(5, N=500)=1.52, p<.05\right)$. The data was considered to be representative of the population in the study.

The 12-item short form of the Teacher Sense of Efficacy Scale (TSES) was used (TschannenMoran \& Woolfolk Hoy, 2001). The individual items are available on Table 1. It has been determined to be a valid measure of self-efficacy when used in the short form (TschannenMoran \& Woolfolk Hoy, 2001). According to Tschannen-Moran and Woolfolk Hoy (2001), the short form of the instrument was a reliable measure with a Cronbach's alpha of $\alpha=.90$ when tested with inservice teachers SBAE teachers were engaged in in-person and online instruction when the instrument was completed. We asked the teachers to rate their efficacy on the scale as it related to their teaching in-person and teaching at a distance (online) using side-by-side matrixes. The scale asked participants to rate their influence on various teaching practices. The anchors of the scale were (1) Nothing, (2) Very Little, (3) Some Influence, (4) Quite a Bit, (5) A Great Deal. Real limits were established for scale interpretation. The real limits were 1.0-1.49= Nothing, 1.5-2.49 = Very Little, 2.5-3.49 = Some Influence, 3.5-4.49 = Quite a bit, 4.5-5.0 = A Great Deal.

The post-hoc reliability was found to be $\alpha=.90$ for the in-person scale and $\alpha=.89$ for the online scale. If multiple items were incomplete from the scale, or the entire scale was missing, the data were omitted from analysis. Data were analyzed using SPSS version 27 . Means and standard deviations were calculated for objectives one and two. A paired samples $t$-test was conducted for objective three. The data were analyzed as a sample data and inferential statistics were calculated to compare the means to reduce the likelihood that differences were due to stochastic error as a complete response rate was not achieved.

\section{Findings}

A total of 248 respondents participated in the study. Of the respondents, $30.2 \%(n=75)$ were male, and $69.8 \%(n=173)$ were female. $89.9 \%(n=213)$ indicated there were white, nonHispanic, 4.2\% $(n=10)$ were Hispanic/Latinx, 2.8\% $(n=7)$ were Black/Non-Hispanic, and 2.8\% ( $n$ $=7$ ) indicated they were another race or bi/multi-racial. The respondents had an average of $12.8(S D=10.3)$ years of teaching experience. Of the respondents, $2.1 \%(n=5)$ reported teaching completely online, $19.0 \%(n=45)$ completely face-to-face, and $78.9 \%(n=187)$ reported teaching a mix of face-to-face and online students.

\section{Objective 1: Determine the self-efficacy of Florida SBAE teachers for in-person instruction}

The teachers were asked to respond to questions on the TSES scale for their in-person instruction. There were valid responses from 246 teachers. The mean reported self-efficacy for the overall scale was $4.22(S D=0.48)$ which corresponds to quite a bit of influence on the scale. The values ranged from 3.00 to 5.00 . 


\section{Objective 2: Determine the self-efficacy of Florida SBAE teachers for online instruction}

The teachers were also to respond to questions on the TSES scale for teaching online. The mean reported self-efficacy for teaching online was $2.98(S D=0.67)$ which is aligned with some influence on the scale. The values ranged from 1.00 to 5.00 .

\section{Objective 3: Compare the self-efficacy of Florida SBAE teachers for delivering instruction at a} distance and in-person.

The individual items used to determine the self-efficacy scale are displayed in Table 1 . The items were treated as scale data, therefore comparisons between individual items were not calculated. The self-efficacy of teachers for in-person and online instruction were compared using a paired samples $t$-test. There was a significant difference $(t(234)=24.5 p<.01)$ between the TSES for teaching in-person $(M=4.22, S D=0.48)$ and teaching online $(M=2.98, S D=0.67)$. There was a large effect size (Cohen's $d=0.79$ ). 
Table 1

Teacher Sense of Self-Efficacy Scale for in-person and online teaching

\begin{tabular}{|c|c|c|c|c|c|c|}
\hline & \multicolumn{3}{|c|}{ In Person } & \multicolumn{3}{|c|}{ Online } \\
\hline & $\mathrm{n}$ & $\mathrm{M}$ & SD & $\mathrm{n}$ & M & SD \\
\hline Overall Self-Efficacy & 246 & 4.22 & 0.48 & 237 & 2.98 & 0.67 \\
\hline $\begin{array}{l}\text { How much can you control disruptive } \\
\text { behavior? }\end{array}$ & 246 & 4.24 & 0.75 & 240 & 2.90 & 1.14 \\
\hline $\begin{array}{l}\text { How much can you do to motivate } \\
\text { students who show low interest in } \\
\text { schoolwork? }\end{array}$ & 246 & 3.88 & 0.78 & 239 & 2.27 & 0.74 \\
\hline $\begin{array}{l}\text { How much can you do to get students } \\
\text { to believe they can do well in } \\
\text { schoolwork? }\end{array}$ & 246 & 4.18 & 0.68 & 239 & 2.79 & 0.88 \\
\hline $\begin{array}{l}\text { How much can you do to help your } \\
\text { students value learning? }\end{array}$ & 246 & 4.02 & 0.78 & 237 & 2.79 & 0.89 \\
\hline $\begin{array}{l}\text { To what extent can you craft good } \\
\text { questions for your students? }\end{array}$ & 246 & 4.28 & 0.68 & 237 & 3.74 & 0.94 \\
\hline $\begin{array}{l}\text { How much can you do to get students } \\
\text { to follow classroom rules? }\end{array}$ & 246 & 4.35 & 0.68 & 238 & 2.93 & 1.00 \\
\hline $\begin{array}{l}\text { How much can you do to calm a } \\
\text { student who is disruptive of noisy? }\end{array}$ & 246 & 4.24 & 0.72 & 237 & 3.03 & 1.24 \\
\hline $\begin{array}{l}\text { How well can you establish a } \\
\text { classroom management system with } \\
\text { each group of students? }\end{array}$ & 246 & 4.38 & 0.63 & 237 & 3.08 & 1.13 \\
\hline $\begin{array}{l}\text { How much can you a variety of } \\
\text { assessment strategies? }\end{array}$ & 246 & 4.39 & 0.68 & 237 & 2.88 & 1.10 \\
\hline $\begin{array}{l}\text { To what extent can you provide an } \\
\text { alternative explanation or example } \\
\text { when students are confused? }\end{array}$ & 246 & 4.48 & 0.58 & 237 & 3.48 & 1.04 \\
\hline $\begin{array}{l}\text { How much can you assist families in } \\
\text { helping their children do well in } \\
\text { school? }\end{array}$ & 246 & 3.93 & 0.78 & 237 & 3.07 & 0.93 \\
\hline $\begin{array}{l}\text { How well can you implement } \\
\text { alternative strategies in your } \\
\text { classroom? }\end{array}$ & 246 & 4.28 & 0.69 & 237 & 2.86 & 0.98 \\
\hline
\end{tabular}

Note. Real limits for the scale are 1.0-1.49 = Nothing, 1.5-2.49 = Very Little, 2.5-3.49 = Some Influence, 3.5-4.49 = Quite a bit, 4.5-5.0 = A Great Deal

\section{Conclusions, Discussion, and Recommendations}

Our first conclusion is that teachers who taught in person courses had a relatively high selfefficacy $(M=4.22, S D=0.48)$ with values that ranged from 3.00 to 5.00 . Our second conclusion 
is that teachers who engaged in online instruction had a significantly lower reported selfefficacy rating than their in-person peers $(M=2.98, S D=0.67)$, with values that ranged from 1.00 to 5.00. Our third conclusion is that when comparing self-efficacy scores for delivering instruction in-person versus online, the self-efficacy rating was an average of 1.24 points higher (scale of 1.00-5.00).

This difference is supported by Bandura's $(1977 b, 1986,1997,2001)$ social cognitive theory and the interactions of personal, behavioral, and social/environmental factors. Self-efficacy shapes how individuals respond to their environment, as well as the belief that one is capable to execute a course of action when faced with challenges (Bandura, 1977a). As teachers addressed challenges due to the COVID-19 pandemic in both their personal and professional lives (WHO, 2021), the modality of instruction had strong impacts on self-efficacy (Cohen's $d=0.79$ ). The results in this study align with previous research that identified challenges teachers faced at the onset of the pandemic, including changes in teaching approaches, educational experiences, and teacher well-being (Easterly et al., 2021). Cardullo et al. (2021) identified factors such as perceived usefulness and system quality as predictors for teacher self-efficacy, or the belief that teachers can successfully motivate students while teaching online.

When looking at types of experiences that are critical in the development of self-efficacy, the areas of mastery experiences, vicarious experiences, social persuasion, and physiological and emotional states should be examined (Bandura 1977a, 1986). The most powerful of these experiences included mastery experiences, by which an individual finds success in attempting a given behavior, and in turn be more likely to attempt the behavior again, ultimately finding themselves successful (Bandura, 1986). In the case of online learning, the frustrations shared by teachers presents a hurdle for mastery experience to occur (Cardulla et al., 2021; Easterly et al., 2021). Additionally, vicarious experiences provide the opportunity for observation of others and their success in completing a given behavior. With common struggles among teachers in the online delivery modality, this reinforcing experience may not have been present for online teachers. The last two experiences presented by Bandura (1986) include social persuasion and physiological and emotional states. Although we do not know the exact social persuasion that was exerted on educators, we can connect the idea that internal feelings and emotions when completing a task can inherently influence self-efficacy (Bandura, 1986; McKim \& Velez, 2016). Although teachers are flexible by nature, the emotional distress of navigating online learning in an already altered environment may have further reduced teachers' self-efficacy (Cardullo et.al., 2021; Easterly, 2021). In addition, teacher attitude and the facilitating conditions in which they teach can influence self-efficacy (Cardullo et al., 2021). Technology issues surfaced in recent research related to remote instruction during COVID-19 (WHO, 2021), and remains a challenge for educators (Easterly et al., 2021). On the contrary, the familiarity of teaching inperson was reflected in a higher reported self-efficacy score for in-person instructors, despite factors that may have provided challenges for this modality (i.e., masks, social distancing, limited teaching practices).

We recommend schools move back into in-person format when it is safe to do so. If online instruction is necessary for a protracted period, or for groups of students in vulnerable 
populations, increased support for online teachers, including training on how to navigate online platforms, and professional development on pedagogical practices for engaging online learners is needed. In addition, teachers should seek teachers who are proficient in online delivery and learn more about successful practices that can be implemented. Practitioners should consider offering teachers training and support in both online pedagogical practices, as well as how to navigate the extra stressors during a global pandemic. Preservice teacher preparation programs should consider including practices to deliver online instruction as part of their coursework.

\section{References}

Bandura, A. (1977a). Self-efficacy: Toward a unifying theory of behavioral change. Psychological Review, 84(2), 191-215. https://www.academia.edu/10120982/Bandura1977 Self efficacy toward a unifying theory of behavior change psychological review 842191215

Bandura, A. (1977b). Social learning theory. Prentice Hall.

Bandura, A. (1986). Social foundations of thought and action: A social cognitive theory. Prentice-Hall.

Bandura, A. (1995). Self-efficacy in changing societies. Cambridge University Press.

Bandura, A. (1997). Self-efficacy: The exercise of control. Freeman.

Bandura, A. (2001). Social cognitive theory: An agentic perspective. Annual Review of Psychology, 52, 1-26. https://doi.org/10.1146/annurev.psych.52.1.1

Bandura, A., Barabranelli, C., Caprara, G. V., \& Pastorelli, C. (1996). Multifaceted impacts of selfefficacy beliefs on academic functioning. Child Development, 67(3), 1206-1222. https://doi.org/10.2307/1131888

Cardullo, V., Wang, C., Burton, M., \& Dong, J. (2021). K-12 teachers' remote self-efficacy during the pandemic. Journal of Research in Innovative Teaching \& Learning, 14(1), 1-

14. https://doi.org/10.1108/JRIT-10-2020-0055

Easterly, R. G., Humphrey, K., \& Roberts, T. G. (2021). The impacts of COVID-19 on school-based agricultural education teachers in the U.S. Advancements in Agricultural Development, 2(1), 1-13. https://doi.org/10.37433/aad.v2i1.79

Easterly, R. G., \& Simpson, K. (2020). An examination of the curricular resource use and self efficacy of Utah school-based agricultural education teachers: An exploratory study. Journal of Agricultural Education, 61(4), 30-45. https://doi.org/10.5032/jae.2020.04035 
Goddard, R. D., Hoy,W. K., \& Hoy, A. W. (2000). Collective teacher self-efficacy: its meaning, measure, and impact on student achievement. American Educational Research Journal, 37(2), 479-507. https://doi.org/10.3102\%2F00028312037002479

Guskey, T. R. (1998). Teacher efficacy, self-concept, and attitudes toward the implementation of instructional innovation. Teaching and Teacher Education, 4(1), 63-69. https://doi.org/10.1016/0742-051X(88)90025-X

Humphries, C. A., Hebert, E., Daigle, K., \& Martin, J. (2012). Development of a physical education teaching efficacy scale. Measurement in Physical Education and Exercise Science, 16(4), 284-299. https://doi.org/10.1080/1091367X.2012.716726

Klassen, R. M., \& Chiu, M. M. (2011). The occupational commitment and intention to quit of practicing and pre-service teachers: Influence of self-efficacy, job stress, and teaching context. Contemporary Educational Psychology, 36(2), 114-129. https://doi.org/10.1016/i.cedpsych.2011.01.002

Lindner, J., Clemons, C., Thoron, A., \& Lindner, N. (2020). Remote instruction and distance education: A response to COVID-19. Advancements in Agricultural Development, 1(2), 53-64. https://doi.org/10.37433/aad.v1i2.39

McKim, A. J., \& Velez, J. V. (2016). An evaluation of the self-efficacy theory in agricultural education. Journal of Agricultural Education, 57(1), 73-90. https://doi.org/10.5032/jae.2016.01073

Schunk, D. H. (2012). Social cognitive theory. In K. R. Harris, S. Graham, T. Urdan, C. B. McCormick, G. M. Sinatra, \& J. Sweller (Eds.), APA handbooks in psychology ${ }^{\circledR}$. APA educational psychology handbook, Vol. 1. Theories, constructs, and critical issues (pp. 101-123). American Psychological Association. https://doi.org/10.1037/13273-005

Swan, B. G., Wolf, K. J., \& Cano, J. (2011). Changes in teacher self-efficacy from the student teaching experience through the third year of teaching. Journal of Agricultural Education, 52(2), 128-139. https://doi.org/10.5032/jae.2011.02128

Talbert, B. A., Vaughn, R., Croom, B., \& Lee, J. S. (2014). Foundations of agricultural education. Pearson-education, Inc.

Tschannen-Moran, M., \& Woolfolk Hoy, A. (2001). Teacher efficacy: Capturing an elusive construct. Teaching and Teacher Education, 17(7), 783-805. https://doi.org/10.1016/S0742-051X(01)00036-1

Thornton, K., Easterly, R. G., \& Simpson, K.A. (2020). Curricular resource use and the relationship with teacher self-efficacy among New Mexico school-based agricultural 
education teachers. Journal of Agricultural Education, 61(4), 343-357.

https://doi.org/10.5032/jae.2020.04343

Wei, H., \& Chou, C. (2020) Online learning performance and satisfaction: Do perceptions and readiness matter? Distance Education, 41(1), 48-69. https://doi.org/10.1080/01587919.2020.1724768

Wolf, K. (2011). Agricultural education perceived self-efficacy: A descriptive study of beginning agricultural education teachers. Journal of Agricultural Education, 52(2), 163-176. https://doi/org/10.5032/jae.2011.02163

World Health Organization (WHO). (2021, March). R\&D Blueprint and COVID-19. https://www.who.int/teams/blueprint/covid-19

(C) 2021 by authors. This article is an open access article distributed under the terms and conditions of the Creative Commons Attribution license (http://creativecommons.org/licenses/by/4.0/). 